\title{
Profiling the Perceptions of Employees at Designated Tourism Establishments: A Survey Based Review
}

\author{
Chengedzai Mafini \\ Faculty of Management Sciences, Vaal University of Technology \\ P.Bag X021, Vanderbij|park, South Africa \\ Email: chengedzai@hotmail.com \\ Mejuri Mafini \\ Faculty of Human Sciences, Vaal University of Technology \\ P.Bag X021, Vanderbijlpark, South Africa \\ Email:mmafini@gmail.com
}

\section{Doi:10.5901/mjss.2014.v5n6p11}

\begin{abstract}
The purpose of this study was to investigate the perceptions of employees at selected tourism establishments in the Vaal Triangle area of Gauteng Province, South Africa. The investigation was conducted in five key areas; namely, manageremployee relationships, working conditions, remuneration, teamwork and work allocation, which affect the satisfaction of employees on their jobs. A six section structured questionnaire was administered to a convenient sample of 164 employees at seven selected tourism establishments. Data were analysed using the Statistical Packages for the Social Sciences (SPSS Version 21.0). Mean scores showed that employees were more satisfied with the level of teamwork that the other four factors. Simple descriptive statistics revealed the existence of satisfactory working conditions, a market-related pay system, acceptable levels of teamwork and equitable work allocation. However, entrenched dysfunctional manager-employee relationships still remain a major challenge at the selected tourism establishments. Based on these results, appropriate recommendations were made.
\end{abstract}

Keywords: Management-employee relationship, working conditions, remuneration, teamwork, work allocation, tourism, South Africa.

\section{Introduction}

Employees are considered as the primary internal customers in any organisation. Their views are special, since they have a significant impact on either the success or failure of the organisation. In the tourism industry, the views of employees are even weightier, since employees are in consistent contact with guests. As such, disregarding the views of employees in a tourism environment is tantamount to corporate suicide and may have severe consequences on the enterprise. It becomes important then, to place special empirical emphasis on tapping the observations made by these employees, with a view to improve the standard of operations in tourism establishments.

Employee perceptions can be directed to almost every aspect of the business. However for the purposes of this study, five elements; specifically, manager-employee relationships, working conditions, remuneration, teamwork and work allocation were identified as critical areas from where perceptions of employees should be collected. The acquisition of employee views on the identified five factors is considered quintessential since these factors have an influence on the success of the organisation. For instance, the perceptions of employees regarding their relationship with management can provide practical guidance on how best managers can relate to employees to obtain the best results (Harter, Schimdt, Asplund, Killham \& Agrawal, 2010). Both employees as well as the organisation also stand to benefit when the views of employees on the working conditions are taken into consideration, since working conditions determine the morale of employees (Kim, McDuffie \& Pil, 2010). Still, since employees work to earn a salary, it is important that their opinions as regards remuneration levels are known, with a view to provide information on whether there is a need to restructure the reward system in the organisation (Demps, Thornton \& Baker, 2011). As suggested by Delarue, VanHootegem, Procter \& Burridhe (2008), teamwork among employees is central because it has a positive impact on all four performance indices in the tourism industry; to be exact, attitudinal, behavioural, operational and financial measures. Additionally, by improving the allocation of tasks in the work environment, many problems associated with workplace 
conflict as well as operating costs can be reduced, resulting in superior performance (David, Rawley \& Polsky, 2011). Therefore, it is supreme that information pertaining to these critical areas be collected empirically on an on-going basis, in order to facilitate the success of the organisation as well as the contentment of all stakeholders at large.

\section{Goal and Objectives of the Study}

The goal of the study was to investigate employee perceptions of selected tourism establishments in Gauteng Province, South Africa. In line with this goal, the following objectives were set for this study:

- To examine the perceptions of employees at selected tourism establishments towards management

- To evaluate the perceptions of employees at selected tourism establishments towards the working conditions

- To examine the perceptions of employees at selected tourism establishments towards their remuneration

- To establish the perceptions of employees at selected tourism establishments towards the levels of teamwork among employees.

- To investigate the perceptions of employees at selected tourism establishments towards allocation of work

\section{Literature Review}

\subsection{Manager-employee relationships}

An organisation may be perceived as a group of people who are gathered together for a specific purpose in order to achieve a desired goal (Katou \& Budhwar, 2007). Since these people are from different fields of expertise, they tend to have different characteristics as well as attitudes towards their work (Hughes \& Parkes, 2013). A number of internal relationships exist within the organisation, including relationships amongst employees, between employees and supervisors and between employees and functional departments (Nielsen,Yarker, Brenners, Randall \& Borg, 2008). However, the relationship between employees and their managers is viewed as one of the most critical. This being the case, it is imperative for managers to appreciate their subordinates in order to ensure that the performance of the organisation is improved (Martins, 2005).

As observed by Yeow and Sen (2006) employees are the central focus of the organisation's activities. Bhattacharya and SankarSen (2003) posit that the right treatment of employees is the first market of the organisation. Accordingly, the creation and management of acceptable internal relationships between management and employees is regarded as a critical activity (Voss, Cable \& Voss, 2006). Based on this, it is essential for managers to cultivate appropriate management styles that promote the well-being of employees. Nielsen, et al. (2008) found a positive relationship between management style and employee well-being through mediation from work characteristics. In addition, Bono and llies (2006) opine that proper management styles create a positive emotion and mood amongst employees. Gilbreath and Benson (2004) further concluded that supervisory behaviour is the most dominant factor compared with other workplace factors that influence the happiness of employees. Therefore, it is important for managers to develop management styles and deportments that facilitate the satisfaction of the needs of employees.

\subsection{Working Conditions}

Working conditions pertain to the circumstances under which an individual works (Forlan \& Browne, 2005). These include the surroundings that influence an individual at work, with examples being facilities, physical environment, and the degree of safety and noise levels. According to Rethinam and Ismail (2008) working conditions involve promoting a work environment conducive to the satisfaction of employee needs. Md-Sidin, Sambasivan and Ismail (2010) view working conditions as a comprehensive factor that includes an individual's job-related well-being and the extent to which work experiences are rewarding, fulfilling and devoid of stress and other negative personal consequences. Yavari, Amirtash and Tondnevis (2009) support that working conditions are meant to capture the extent to which the work environment, job requirements, supervisory behaviour, and ancillary programs in an organisation meet the needs of an employee.

The impact of working conditions overarches to a number of other life domains such as family life, leisure life, social life, financial life, among others (Nurmala, 2010). Mubarak, Baba, Low and Quah (2003) noted that working conditions relate not only to how people can do work better, but also to how work may cause people to be better. Working conditions in an organisation also concern the participation of workers in problem solving and decision making (Lynch, 2004). Moreover, better working conditions correlate positively with lower work-to-family interference (Md-Sidin et al., 
2010). Working conditions are also associated with both the health and well-being of employees (Mead, Witkowski, Gault \& Hartmann, 2003). Poor working conditions may be an important source of stress and may therefore contribute to the development of depressive and anxiety disorders (Fabiano, Curro, Reverberi \& Pastorino, 2008).

Other working conditions potentially associated with health behaviours include working overtime, work fatigue, physically strenuous work and mentally strenuous work (Holcroft \& Punnett, 2009). However, although working overtime is often seen as a benefit for the employer, its consequences might bear costs for the employer as well as for the employee as health problems increase (Lynch, 2004). Varonen and Mattila (2003) emphasise the importance of safety climate, showing that the more safety-conscious the climate of the company, the lower the accident rate. Issues such as physical workload, machine-paced work or inability to take a break when tired, lack of training, absence of a lockout program, low seniority and gender are also associated with high injury risk through accidents (Tangen, 2004). In view of this, it is advisable for organisations to improve the working conditions of employees by ensuring that safety training is given to employees (Attwood, Khan \& Veitch, 2006).

\subsection{Remuneration}

Remuneration is the reward or compensation given to employees for performing their work (Schutte \& Eaton, 2004). Katou and Budhwar (2007) contend that most successes or problems in organisations can be traced back to the level of satisfaction with employee rewards as well as the competency of human resources. Organisations recognise that people are the true agents in business and that all assets and structures, whether tangible or intangible, are the result of human actions (Guthrie \& English, 1997). This could explain why most organisations locally and internationally invest astronomical amounts of money in attracting and placing human talent (Ireland, Hoskisson \& Hitt, 2009).

A salary is an important source of income for employees since it determines their standard of living. Salaries also determine the productivity and work performance of employees (Yang, 2008). Van Herpen, Van Praag and Cools (2005) acknowledge that remuneration has a major impact on organisations' capability to catch, retain and motivate high potential employees. Estes \& Micheal (2005) opine that well-remunerated employees are likely to perform the job efficiently and effectively. Remuneration is a factor in employee retention because it is a component of job satisfaction (Cropanzano \& Mitchell, 2005). Furthermore, remuneration is a factor in career choice, as well as the salary gradient between positions and practice opportunities in organisations (Beardsle, Matzke \& Rospond, 2008). This demonstrates that the amount and method of remuneration is central to the company's production.

Salaried employment minimises fluctuations in pay, thus giving workers some degree of certainty about their income into the future, provided they reach the performance threshold necessary to retain their job and provided the employer remains in business (Kuvaas \& Dysvik, 2009). Bandiera, Barankay and Rasu (2007) emphasise the role performance bonuses can play in improving worker productivity, an effect that comes through focusing their efforts on the most able workers and in recruiting and retaining better workers. Yang (2008) claimed that if employee performance is observable then organisations can use direct bonuses or relational contracts to motivate them based on their performance. Remuneration remains a significant factor that positively influences the satisfaction of employees in varied settings.

\subsection{Teamwork}

A team is a group of employees who are authorised to regulate mutually the execution of some collective tasks (Tohidi \& Glard, 2008). Ferreira (2009) define a team as a small number of people, with a set of performance goals, who have a commitment to a common purpose and an approach for which they hold themselves mutually accountable. According to Delarue et al. (2008), teamwork is concerned with the prevalence of joint actions by a group of people, in which each individual subordinates his or her individual interests to those of the group. These definitions commonly place people and the idea of working corporately toward a common goal at the epicenter of teams.

Effective teamwork has a substantial bearing in organisations. Chandrasekar (2011) throws spotlight on the fact that teamwork is one of the job factors that can motivate the performance of employees in organisations so that they can reach their expected targets. Moreover, teamwork in the organisation can be a noteworthy contributor to improved performance of the organisation because team players are more likely to be very satisfied with their current jobs than employees who do not do teamwork (Origo \& Pagani, 2009). Jao (2010) adds that teamwork creates an environment that facilitates knowledge and information exchange and the sharing of knowledge, leading to greater innovation. Ferreira (2009) observed that teamwork leads to greater oneness and a sense of belonging between employees. It also improves the attitudes and of employees, leading to high productivity and company performance of the organisation (Delarue et al., 
2008).

There are several challenges associated with teamwork. In some cases, there may be resistance from employees who are not comfortable to work in teams that comprise of individuals they are not familiar with (Hoegl, Weinkauf \& Gemuenden, 2004). This resistance stems from the fact that such teams tend to effectively break up established social relationships (Delarue et al., 2008). In addition, teamwork may be associated with conflict, where team members are mismatched or disagree with each other, leading to sour relationships (Jao, 2010). In certain cases, minority domination may exist in which a few individual extroverts tend to dominate the team and expect everyone to subscribe to their ideas (Holcroft \& Punnett, 2009). Cases exist in which some managers do not trust teams enough to let them make major decisions (Shikdar \& Sawaqed, 2003). In such instances, teams and the organisation to which they belong may fail to reach their full potential.

\subsection{Work allocation}

Work allocation is the process that results in specific workers being engaged in clear tasks, in numbers appropriate to the current situation (Duarte, Pen, Keller \& Weissing, 2012). In other words, it occurs when managers give each employee specific work to do. When work is allocated equitably, employees will be motivated to do their work. However, when employees are not satisfied with the mode of work allocation, they typically become disgruntled and they may seek for employment opportunities elsewhere (Bolton, 2007). Lazear and Gibbs (2009) suggest that managers should allocate work to employees on a fair basis, taking account of their skills, knowledge and understanding, experience and workloads, and the opportunity for development. For example, haphazard work allocation may result in a scenario where some employees will be inundated with work, while others have fewer responsibilities. This may lead to the proliferation of dysfunctional conflict in the workplace. In addition, those who have been allocated more work may be overworked leading to loss of production and despondency in the workplace (Duarte et al., 2012).

O'Donnell and Bulova (2007) highlight that some employees have higher abilities than others, which makes it necessary to allocate work in line with the abilities of employees. Correct work allocation has other advantages to the organisation, such as growth of total output in terms of the production levels of both individual employees and the company (Yoon \& Suh, 2003). This signifies that in order for the organisation to develop positively, managers must be able to allocate work in such a manner that the organisation will benefit in the end (Origo \& Pagani, 2009).

\section{Research Methodology}

\subsection{Research design}

Quantitative research using the survey method was used for the empirical portion of the study. The survey research method was deemed as desirable for the current study since it uses questionnaires to obtain data from a sample of respondents selected from the population, which made it directly applicable to this study (Chai \& Xiao, 2012).

\subsection{Participants}

The research was conducted among employees at seven selected tourism establishments which are located in the Vaal Triangle area of Southern Gauteng, South Africa. The-non probability convenience sampling technique was used to select respondents. In convenience sampling, respondents are selected on the premise that they are readily available or easily accessible (Collis \& Hussey, 2009). In the current study, convenience sampling was used because it was difficult to access all the respondents at the selected tourism establishments at the same time.

Sample size was determined using the available historical information. Previous studies on matters related to manager-employee relationships, working conditions, remuneration, teamwork and work allocation which were conducted by researchers such as Ericksen and Dyer (2005); Katou and Budhwar (2007), Watson et al. (2007) suggest that 300 respondents are adequately representative. This being the case, the size of the sample was initially set at $n=300$ respondents.

\subsection{Instrumentation}

Data were collected using a structured questionnaire. The questionnaire was deemed appropriate for collecting primary data in this study because it encourages honest answers, limits the researcher's bias, makes answers easy to collect, 
tabulate and analyse, is cheap to administer, requires less time, permits data collection from larger samples, and allows greater respondents' anonymity (Drew, Hardman \& Hosp, 2008).

The questionnaire was divided into six echelons. Section A elicited the respondents' demographic information. Section B consisted of six questions adapted from Booth and Hamer (2000) and Bono and llies (2006) that elicited the respondents' views on their relationship with their managers. In Section C, there were seven questions that prompted the respondents' perceptions of their working conditions. These questions were adapted from two studies conducted by Lynch (2004) and Kinzl et al. (2004). Section D was composed of four questions (adapted from Fay \& Thompson, 2004; Bockerman \& IImakunnas, 2006) that elicited the respondents views on their levels of remuneration. In Section E were six questions adapted from Delarue et al. (2008) and Kim et al. (2010) that elicited information on teamwork. Section F consisted of six questions adapted from Ruhala et al. (2007) as well as David, Rawley and Polsky (2011) that elicited information on work allocation. The questions in Sections B to $\mathrm{F}$ were scored on a 5 point Likert Scale with 1 expressing strongly disagree and 5 strongly agree. The respondents were requested to indicate their scores on this range in the scale.

\subsection{Survey}

After their development, questionnaires were administered to employees at the selected tourism establishments during the month of July 2013. Respondents were given a period of about 5 days to complete the questionnaire. In collecting the data, the researcher adhered to the following ethical considerations;

- Right to anonymity: Identities of respondents remained anonymous.

- Right to confidentiality: The research was not made available for use outside the agreement made with the subjects.

- Right to privacy or non-participation: Respondents were not to be coerced into participating in the research.

- Informed consent: All prospective research participants were fully informed about the procedures and risks involved in research and had to give their consent to participate.

- Right to Protection from discomfort or harm: All research participants were protected from any circumstance that was likely to cause them any form of discomfort and physical or emotional harm.

\subsection{Data analysis}

A computerized statistical package (SPSS Version 21.0) was used in the analysis of data. Data were analysed using frequency distributions and measures of central tendency.

\section{Research Results}

\subsection{The profile of respondents}

A total of 300 respondents were initially requested to participate in the study. However, 164 usable questionnaires were eventually collected and used in the data analysis, which gave a response rate of nearly $55 \%$. The demographic characteristics of these respondents are reported in Table 1.

Table 1: Demographic Profile of Respondents

\begin{tabular}{llccc}
\hline Parameter & Description & N & N & $\%$ \\
\hline Gender & Male & 164 & 91 & 55 \\
Age groups & Female & 164 & 73 & 45 \\
& $18-29$ & 164 & 57 & 35 \\
& $30-39$ & 164 & 61 & 37 \\
\multirow{3}{*}{ Racial Groups } & $40-49$ & 164 & 33 & 20 \\
& $\geq 50$ & 164 & 13 & 8 \\
& Black & 164 & 117 & 71 \\
& White & 164 & 39 & 24 \\
& Indian & 164 & 6 & 4 \\
\hline & Coloured & 164 & 2 & 1 \\
\hline
\end{tabular}




\begin{tabular}{|llccc}
\hline Type of contract & Permanent & 164 & 53 & 32 \\
& Contract & 164 & 79 & 48 \\
No of years employed & Part time & 164 & 32 & 20 \\
& $<1$ year & 164 & 56 & 34 \\
& $1-2$ years & 164 & 42 & 26 \\
& 3-5 years & 164 & 37 & 23 \\
& 6-9 years & 164 & 14 & 8 \\
\hline \multirow{3}{*}{ Department } & $\geq 10$ years & 164 & 15 & 9 \\
& Human Resources & 164 & 7 & 4 \\
& Marketing & 164 & 19 & 12 \\
& Finance & 164 & 5 & 3 \\
& Reception & 164 & 8 & 5 \\
& Food and beverage & 164 & 60 & 37 \\
& Housekeeping and gardens & 164 & 24 & 15 \\
& Security & 164 & 16 & 9 \\
& Casino & 164 & 25 & 15 \\
\hline
\end{tabular}

As chronicled in Table 1, 55\% ( $n=91)$ of the respondents were male whereas $45 \%(n=73)$ of respondents were female. After collapsing the age groups, it emerged that a majority of the respondents $(72 \% ; n=118)$ were aged between 18 and 39 years. This demonstrates that the tourism establishments employ more young individuals than older people. In terms of racial groups, the results show that approximately $71 \%(n=117)$ of the respondents were blacks. This attests to the fact that the results of the study at most represent the views of the largest group of respondents, who were blacks. Most of the respondents were either employed on contract basis (48\%; $n=79)$, or permanently $(32 \% ; n=53)$. With regard to the number of years employed, it was observed that in the mainstream (83\%; $n=135)$, respondents were employed for periods of less than five years at the time of the study. With reference to the department where the respondents were employed, it emerged that at least $37 \%(n=60)$ of the respondents were employed in the Food and Beverages department while $30 \%$ ( $n=49$ ) of the respondents were from the Housekeeping and Casino departments, respectively.

\subsection{Validity and reliability}

To determine the face and content validity of the measuring instrument, a panel consisting of three experts in the discipline of tourism management was asked to review the questionnaire items to assess their ability to clearly measure the constructs under consideration. A pre-test involving 20 conveniently selected respondents was also conducted. These two protocols facilitated the further refinement of the questionnaire items, based on the contribution of the panel of experts as well as the pre-test sample. The internal consistencies of the scales in the measuring instrument were measured using the Cronbach alpha coefficient. These internal consistencies are reported in Table 2. The Cronbach alpha values for the scales ranged between 0.722 and 0.871 . Additionally, the alpha value for the overall scale was 0.794. Since these values were all above the acceptable threshold level of 0.70 which is prescribed by Malhotra (2009), it can be concluded that the measurement scales used in the study were internally consistent or reliable.

Table 2: Mean scores and internal consistencies of scales

\begin{tabular}{lcccc}
\hline \multicolumn{1}{c}{ Dimension description } & Number of items & $\begin{array}{c}\text { Cronbach } \\
\text { Alpha }\end{array}$ & Mean score & Position in mean score rank \\
\hline Manager-Employee Relationship & 6 & 0.722 & 1.629 & 5 \\
Working Conditions & 7 & 0.871 & 3.901 & 4 \\
Remuneration & 4 & 0.707 & 3.924 & 3 \\
Teamwork & 6 & 0.713 & 4.455 & 1 \\
Work Allocation & 6 & 0.845 & 4.163 & 2 \\
Overall Scale & 35 & 0.794 & 4.527 & Not applicable \\
\hline Scale: 1= Strongly Disagree: 2=Disagree: 3=Neutral: 4=Agree: 5=Strongly agree & \\
\hline
\end{tabular}

Table 2 also provides a statistical narrative of the mean scores of the dimensions considered in the study. The meanscores for working conditions, remuneration, teamwork and work allocation ranged between 3.901 and 4.455, which represents clear inclinations towards either the agree/strongly agree positions on the Likert scales. This result demonstrates that respondents were satisfied with the existing levels of these factors in their organisation. However, the 
manager-employee relationship factor attained a mean score of 1.629, which represents an average scoring between disagree and strongly disagree on the Likert scale. This implies that respondents were dissatisfied with the level of manager-employee relationships at the selected tourism establishments. On comparing the mean scores, it was observed that respondents were most satisfied with the level of teamwork $(\bar{X}=4.455)$ and most dissatisfied with manager-employee relationship ( $\bar{X}=1.629$ ).

\subsection{Manager-employee relationship}

The results on the perceptions of respondents vis-à-vis manager-employee relationships at the selected tourism establishments are illustrated in Table 3.

Table 3: Frequencies and percentages regarding perceptions on manager-employee relationships

\begin{tabular}{|c|c|c|c|c|c|c|c|}
\hline $\begin{array}{l}\text { Item } \\
\text { Number }\end{array}$ & ITEM & $\mathrm{N}$ & $\begin{array}{c}\text { Strongly } \\
\text { Disagree (1) }\end{array}$ & $\begin{array}{l}\text { Disagree } \\
\text { (2) }\end{array}$ & $\begin{array}{l}\text { Neutral } \\
(3)\end{array}$ & $\begin{array}{l}\text { Agree } \\
(4)\end{array}$ & $\begin{array}{l}\text { Strongly } \\
\text { agree (5) }\end{array}$ \\
\hline 1 & I feel accepted by my managers & 164 & $55(34 \%)$ & $51(31 \%)$ & $15(9 \%)$ & $28(17 \%)$ & $15(9 \%)$ \\
\hline 2 & My managers give me positive feedback on my work & 164 & $36(22 \%)$ & $63(38 \%)$ & $21(13 \%)$ & $34(21 \%)$ & $10(6 \%)$ \\
\hline 3 & My managers reward me when I do well & 164 & $44(27 \%)$ & $51(31 \%)$ & $7(4 \%)$ & $24(15 \%)$ & $38(23 \%)$ \\
\hline 4 & $\begin{array}{l}\text { My leaders give me personal attention when I feel } \\
\text { rejected }\end{array}$ & 164 & $38(23 \%)$ & $46(28 \%)$ & $26(16 \%)$ & $24(15 \%)$ & $30(18 \%)$ \\
\hline 5 & $\begin{array}{l}\text { I have faith in the quality of leadership of my } \\
\text { superiors }\end{array}$ & 164 & $28(17 \%)$ & $28(17 \%)$ & $54(33 \%)$ & $36(22 \%)$ & $18(11 \%)$ \\
\hline 6 & My managers value my input & 164 & $44(27 \%)$ & $50(30 \%)$ & $21(13 \%)$ & $39(24 \%)$ & $10(6 \%)$ \\
\hline
\end{tabular}

An analysis of Table 3 yielded one dominant observation. Respondents gave negative reflections of their relationship with their managers. For instance, approximately $64 \%(n=105)$ of respondents felt that they were not accepted by their managers while nearly $60 \%(n=98)$ of respondents felt that their managers were failing to provide them with positive feedback on their work. Additionally, approximately $58 \%(n=95)$ of respondents felt that their leaders did not reward them when they did well and about $51 \%(n=84)$ professed that they suffered from a lack of personal attention from managers when they faced various challenges. Approximately $57 \%(n=94)$ of respondents indicated that their managers did not value their input while 34\% $(n=56)$ indicated that they doubt the credibility of their managers. At most, these results demonstrate the absence of meaningful relationships between employees and management.

The status quo in the tourism establishments is extremely dysfunctional since it has been established in research that a harmonious relationship between management and employees in an organisation is associated with a cocktail of indispensible pertinent paybacks. Noblet, Graffam and McWilliams (2008) advocate that employees who are given an opportunity to take part in discussions have a better feeling of belongingness, which leads to better mental health. Additionally, Booth and Hame (2007) observed that there were reduced stress levels among employees in democratic management workplaces than in traditional management workplaces where employees do not participate in decisionmaking. Managerial support that allows employee feedback and bilateral communication in an organisation is also important because it improves employees' well-being (Kassahun, 2005). Managers who are under pressure may affect their subordinates by bullying them, which causes most of the subordinates to suffer from depression and other ill health problems (Zairi \& Jarrar, 2006). Merriman, Schmidt, Ross \& Dunlap-Hinkler (2004) further underscore that managers in contemporary organisations should understand that their behaviours can severely alter the efficiency, productivity, morale, quality, and culture of their organisations if they damage workplace trust. Lufkin (2006:1) adds that an effective manager is one who is able to "manage expectations, monitor stress levels, and make every effort to know" his/her subordinates. It appears then that this aspect is lacking at the selected tourism establishments and a need exists to invoke strategic modifications in this area.

\subsection{Working conditions}

The respondents' perceptions on working conditions at the selected tourism establishments are reported in Table 4. 
Table 4: Frequencies and percentages regarding perceptions on working conditions

\begin{tabular}{|c|c|c|c|c|c|c|c|}
\hline $\begin{array}{c}\text { Item } \\
\text { Number }\end{array}$ & ITEM & $\mathrm{N}$ & $\begin{array}{c}\text { Strongly } \\
\text { Disagree (1) }\end{array}$ & $\begin{array}{c}\begin{array}{c}\text { Disagree } \\
(2)\end{array} \\
\end{array}$ & $\begin{array}{c}\text { Neutral } \\
(3)\end{array}$ & $\begin{array}{c}\text { Agree } \\
(4)\end{array}$ & $\begin{array}{l}\text { Strongly } \\
\text { agree (5) }\end{array}$ \\
\hline 1 & I work for an acceptable number of hours & 164 & $30(18 \%)$ & $26(16 \%)$ & $21(13 \%)$ & $33(20 \%)$ & $54(33 \%)$ \\
\hline 2 & $\begin{array}{l}\text { I feel satisfied with the quality of facilities that are } \\
\text { available for my job }\end{array}$ & 164 & $0(00 \%)$ & $20(12 \%)$ & $16(10 \%)$ & $67(41 \%)$ & $61(37 \%)$ \\
\hline 3 & The leave/vacation policy is fair & 164 & $13(8 \%)$ & $28(17 \%)$ & $12(7 \%)$ & $72(44 \%)$ & $39(24 \%)$ \\
\hline 4 & $\begin{array}{l}\text { There are opportunities for professional } \\
\text { development on my job }\end{array}$ & 164 & $10(6 \%)$ & $39(24 \%)$ & $25(15 \%)$ & $54(33 \%)$ & $36(22 \%)$ \\
\hline 5 & Company policies are implemented fairly & 164 & $18(11 \%)$ & $26(16 \%)$ & $77(47 \%)$ & $39(24 \%)$ & $4(2 \%)$ \\
\hline 6 & I work in a suitable environment/surroundings & 164 & $28(17 \%)$ & $31(19 \%)$ & $(00 \%)$ & $41(25 \%)$ & $64(39 \%)$ \\
\hline 7 & My supervisor is competent in making decisions & 164 & $34(21 \%)$ & $73(44 \%)$ & $34(21 \%)$ & $23(14 \%)$ & $0(00 \%)$ \\
\hline
\end{tabular}

The statistical account presented in Table 4 reveals that at most, respondents felt that the working conditions at the selected tourism establishments were satisfactory. The majority of respondents $(53 \% ; n=87)$ concurred that they worked for acceptable hours. Approximately $78 \%(n=128)$ of respondents further expressed satisfaction with the quality of facilities that are available for their jobs and at least $68 \%(n=112)$ of the respondents felt that the leave or vacation policies in place in their establishments were fair. A total of $55 \%(n=90)$ of the respondents consented that there were opportunities for professional advancement in the company whilst most of the respondents $(64 \% ; n=105)$ agreed that they worked in suitable environments or surroundings. Be that as it may, there were still concerns from most of the respondents $(65 \%$; $n=107)$ who noted that the only challenge on their working conditions appears to be the incompetence of their supervisors.

There are a number of benefits that the selected tourism establishments stand to realise by maintaining the satisfactory working conditions that currently exist in their organisations. As acknowledged by Kinzl et al. (2004) the environment in which individuals works could influence their level of pride in themselves and the work they do. Spitzer (2007) further pinpoints that if individuals work in clean, friendly environments they are more likely to be satisfied and look forward to their jobs. A world-class working environment also makes it easier for employees to accomplish their tasks (Turkyilmaz, Akman, Ozkan \& Pastuszak 2011). Hall (2003) supports the notion that working conditions determine the level of satisfaction that an individual experiences. Employees prefer to work in environments where lighting, temperature, noise and other environmental factors are safe and comfortable (Van Emmerik, 2004). In the same vein, Krueger, Brazil, Lohfield, Edward, Lewis and Tjam (2002) propose that a good working environment results in the satisfactory performance of the organisation. It is an important supposition then, to assume that the selected tourism establishments are some of those organisations whose ethos is anchored in the provision of state of the art working conditions for its human resource base.

\subsection{Remuneration}

The respondents' views on remuneration at the selected tourism establishments are reported in Table 5.

Table 5: Frequencies and percentages regarding perceptions on remuneration

\begin{tabular}{clcccccc}
\hline $\begin{array}{c}\text { Item } \\
\text { Number }\end{array}$ & ITEM & N & $\begin{array}{c}\text { Strongly } \\
\text { Disagree (1) }\end{array}$ & $\begin{array}{c}\text { Disagree } \\
\text { (2) }\end{array}$ & $\begin{array}{c}\text { Neutral } \\
\text { (3) }\end{array}$ & $\begin{array}{c}\text { Agree } \\
\text { (4) }\end{array}$ & $\begin{array}{c}\text { Strongly } \\
\text { agree (5) }\end{array}$ \\
\hline $\mathbf{1}$ & My salary is market related & 164 & $34(21 \%)$ & $27(16 \%)$ & $21(13 \%)$ & $41(25 \%)$ & $41(25 \%)$ \\
$\mathbf{2}$ & I feel happy with the benefits I receive & 164 & $23(14 \%)$ & $13(8 \%)$ & $0(00 \%)$ & $69(42 \%)$ & $62(38 \%)$ \\
3 & The salary policies at my company are fair & 164 & $0(00 \%)$ & $46(28 \%)$ & $16(10 \%)$ & $53(32 \%)$ & $49(30 \%)$ \\
$\mathbf{4}$ & My salary is sufficient to meet my needs & 164 & $8(5 \%)$ & $61(37 \%)$ & $10(6 \%)$ & $47(29 \%)$ & $38(23 \%)$ \\
\hline
\end{tabular}

A scrutiny of the results as presented in Table 5 shows the interesting trend of satisfaction with various aspects linked to remuneration at the selected tourism establishments. For instance, approximately $50 \%(n=82)$ of the respondents confirmed that their salaries were market related while the majority of respondents $(80 \%$; $n=131)$ professed that they were happy with the benefits they receive. Additionally, at least $62 \%(n=102)$ of the respondents demonstrated the conviction that the remuneration policies at the company are impartial and $52 \%(n=85)$ revealed that their salaries were 
adequate to meet their needs. These results are illustrative of the companys' resolve to ensure that employees get appropriate material rewards for their efforts.

As suggested by Barbie (2010), the inadequate performance of employees in most organisations could be attributed in part, to dissatisfaction with remuneration. High and recurring incidence of industrial action, turnover, absenteeism and excessive unionism within organisations may be symptomatic of employees' dissatisfaction the existent reward system (Nilsson, 2010). A study conducted by Van den Berg (2006) concluded that remuneration is strongly and positively related to the well-being of employees. A comparative study of public and private sector organisations conducted by Stedham, Yamamura and Satoh (2006) found that public sector employees are less extrinsically motivated and satisfied with their work because their remuneration is significantly lower than what their counterparts in the private sector earn. An evaluation of employee perceptions in Greece showed that employees believe that extrinsic motivational instruments, more specifically the provision of fair wages as an effective tool to improve productivity Cardoso and Portugal (2006). Similar conclusions were drawn by Lazear and Oyer (2004) in a study that examined the satisfaction of employees. Frye (2004) further argues that an increase in wages improves the efficiency of the organisation by enhancing the motivation of the employees. Gavrel and Lebon (2008) show that introducing a market related wage may improve market efficiency by reducing the mismatch between workers and jobs. Some empirical studies reveal that pay incentives affect the behaviour of employees in particular parts of the public sector (Lazear \& Oyer, 2004). It may be suggested then that in order to sustain its operational success, it is vital for the selected tourism establishments to maintain their posture of ensuring that employees at the company are well remunerated.

\subsection{Teamwork}

The respondents' perceptions on the degree of teamwork in their tourism establishments are summarised in Table 6.

Table 6: Frequencies and percentages regarding perceptions on teamwork

\begin{tabular}{|c|c|c|c|c|c|c|c|}
\hline $\begin{array}{l}\text { Item } \\
\text { Number }\end{array}$ & ITEM & $\mathrm{N}$ & $\begin{array}{c}\text { Strongly } \\
\text { Disagree (1) }\end{array}$ & $\begin{array}{l}\text { Disagree } \\
\text { (2) }\end{array}$ & $\begin{array}{l}\text { Neutral } \\
\text { (3) }\end{array}$ & $\begin{array}{c}\text { Agree } \\
(4)\end{array}$ & $\begin{array}{l}\text { Strongly } \\
\text { agree (5) }\end{array}$ \\
\hline 1 & I feel accepted by my work colleagues & 164 & $0(00 \%)$ & $31(19 \%)$ & $18(11 \%)$ & $67(41 \%)$ & $48(29 \%)$ \\
\hline 2 & I receive help from my colleagues when I need it & 164 & $5(3 \%)$ & $20(12 \%)$ & $21(13 \%)$ & $57(35 \%)$ & $61(37 \%)$ \\
\hline 3 & There is a sense of oneness among work colleagues & 164 & $7(4 \%)$ & $26(16 \%)$ & $39(24 \%)$ & $67(41 \%)$ & $25(15 \%)$ \\
\hline 4 & $\begin{array}{l}\text { There is a high level of professionalism and among } \\
\text { my colleagues }\end{array}$ & 164 & $30(18 \%)$ & $15(9 \%)$ & $20(12 \%)$ & $43(27 \%)$ & $56(34 \%)$ \\
\hline 5 & Conflict between colleagues is minimum & 164 & $46(28 \%)$ & $18(11 \%)$ & $13(8 \%)$ & $36(22 \%)$ & $51(31 \%)$ \\
\hline 6 & $\begin{array}{l}\text { I have established the relationships that I need to do } \\
\text { my work properly }\end{array}$ & 164 & $36(22 \%)$ & $31(19 \%)$ & $(00 \%)$ & $71(43 \%)$ & $26(16 \%)$ \\
\hline
\end{tabular}

It is noteworthy to report that there appears to be sustained teamwork at the selected tourism establishments. About $70 \%$ $(n=115)$ of the respondents indicated that they felt accepted by their work colleagues. A further $72 \%(n=118)$ of the respondents revealed that they regularly received help from their work colleagues and $56 \%(n=92)$ of respondents perceived that a sense of camaraderie exists in among employees in their establishments. Almost $61 \%(n=100)$ respondents attested to the existence of high levels of professionalism amongst employees and around $53 \%(n=87)$ of respondents pointed out that there was minimum dysfunctional conflict between employees. Consistently, roughly $59 \%$ $(n=97)$ of the respondents stated that they have well established relationships with their peers at work. These findings demonstrate that there is solidarity, cooperation and harmony within the workforce at the selected tourism establishments, a scenario that is a key success factor in organisations.

In ensuring that there is sufficient teamwork at the selected tourism establishments, it has to be noted that although there are various types of teams, smaller teams tend to be more effective than larger teams, since the sharing of technical and coordinative information within the team becomes significantly more difficult as the number of team members increases (Easley \& Devaraj, 2003). Communication plays an essential role in a dynamic team, in maintaining shared situation awareness and in coordinating team activities formation (Lynch \& Cole, 2006). Human teamwork depends on handling and sharing information (McClellan, Greenwood \& Benger, 2006). In line with this fact, team members typically tend to proactively seek new information to achieve their joint goals (Salas, Sims \& Burke, 2005). Furthermore, teams, like any other organisational unit, also need adequate staffing in terms of both quality and quantity of personnel (Bebchuk \& Fried, 2003). A team's work performance depends on its ability to efficiently and effectively work in a directly interactive mode to achieve a common team output (Frye, 2004). Teamwork quality has been shown to be 
directly related to team performance and this effect becomes stronger as the innovativeness of the team task increases (Hoegl et al., 2004). It seems that these teamwork patterns have been established at the selected tourism establishments.

\subsection{Work allocation}

The respondents' perceptions concerning work allocation at the selected tourism establishments are illustrated in Table 7.

Table 7: Frequencies and percentages regarding perceptions on work allocation

\begin{tabular}{|c|c|c|c|c|c|c|c|}
\hline $\begin{array}{l}\text { Item } \\
\text { Number }\end{array}$ & ITEM & $\mathrm{N}$ & $\begin{array}{c}\text { Strongly } \\
\text { Disagree (1) }\end{array}$ & $\begin{array}{l}\text { Disagree } \\
\text { (2) }\end{array}$ & $\begin{array}{c}\text { Neutral } \\
(3)\end{array}$ & $\begin{array}{l}\text { Agree } \\
\text { (4) }\end{array}$ & $\begin{array}{l}\text { Strongly } \\
\text { agree (5) }\end{array}$ \\
\hline 1 & I have a clear understanding of what is expected of me & 164 & $34(21 \%)$ & $18(11 \%)$ & $25(15 \%)$ & $53(32 \%)$ & $34(21 \%)$ \\
\hline 2 & I am happy with the amount of work I do & 164 & $10(6 \%)$ & $8(5 \%)$ & $0(00 \%)$ & $80(49 \%)$ & $66(40 \%)$ \\
\hline 3 & I am allowed to make my own decisions & 164 & $7(4 \%)$ & $11(7 \%)$ & $47(29 \%)$ & $38(23 \%)$ & $61(37 \%)$ \\
\hline 4 & My job keeps me busy most of the time & 164 & $0(00 \%)$ & $54(33 \%)$ & $0(00 \%)$ & $77(47 \%)$ & $33(20 \%)$ \\
\hline 5 & $\begin{array}{l}\text { My job provides me with the opportunity to do different } \\
\text { things from time to time }\end{array}$ & 164 & $36(22 \%)$ & $28(17 \%)$ & $0(00 \%)$ & $43(26 \%)$ & $57(35 \%)$ \\
\hline 6 & $\begin{array}{l}\text { I have the chance to do things that are not against my } \\
\text { conscience }\end{array}$ & 164 & $0(00 \%)$ & $6(4 \%)$ & $23(14 \%)$ & $70(43 \%)$ & $65(39 \%)$ \\
\hline
\end{tabular}

An exploration of Table 7 discloses that on the overall, the approach to work allocation is satisfactory. Approximately $53 \%$ $(n=87)$ of the respondents indicated that they clearly understood their expected roles whilst an overwhelming $89 \%$ $(n=146)$ affirmed that they were happy with the amount of work they did. A notable $60 \%(n=98)$ of the respondents attested that they are permitted to make their own decisions on their jobs and a further $67 \%(n=110)$ confirmed that their job keeps them busy most of the time. Another $61 \%(n=100)$ of the respondents were happy with the fact that their jobs provided them with the chance to do different things from time to time. Finally, approximately $82 \%(n=135)$ of the respondents agreed that they have the opportunity to do things that are not against their conscience. It can be concluded then that work is allocated in a manner that is equitable and employee-friendly at the selected tourism establishments.

According to O'Donnell and Bulova (2007) some employees have higher abilities than others. Such employees should be allocated work that is in line with their abilities. Proper work allocation adds competitive advantages to the company, such as the growth of total output in terms of the production levels of both individual employees and the company. This means that in order for the company to grow, managers must be able to give out work to employees in such a way that the organisation will benefit in the end (Origo \& Pagani, 2009). Furthermore, managers who do not clarify the roles and duties of their employees might cause role conflict and role ambiguity among employees. Yang (2008) also upholds that role ambiguity and role conflict may cause an individual to suffer from emotional exhaustion and depersonalisation.

Work allocation patterns make a major contribution to the effective and efficient operation of the organisation (Croxon, Propper \& Perkins, 2003). Abd-El-Fattah (2010) found that the majority of resignations in organisations can be attributed to disappointment with wok allocation within the organisation. This suggests that there is an established positive association between work allocation and the job satisfaction of employees (Young, 2009). Furthermore, work allocation has a significant relationship with organisational performance (Adebayo \& Ogunsina, 2011). Satisfaction with work allocation was also found to be among the top four factors that influence employee satisfaction (Boreham, Gray, \& Blake, 2006). Roelen, Koopmans and Groothoff (2008) also add that quality of supervision has emerged as the impeding challenge to the development and success of organisations (both public and private) in any country because it determines the extent to which employees are satisfied with and motivated to achieve organisational goals. Therefore, effective work allocation maintains and even enhances the overall competitive viability of the production channel (Bebchuk \& Fried, 2003).

\section{Limitations and Implications for Further Research}

It is difficult to find an empirical study that is devoid of limitations. This makes it necessary to highlight a number of limitations associated with this study. To start with, restraint should be exercised in attempting to generalise this study to other settings and contexts, since the findings of the present study are based on a small sample that was drawn from a single organisation. In line with this limitation, future studies may be considered using larger samples recruited from other 
organisations that were not included in this study. Another drawback of the study is that the data analysis did not go beyond simple descriptive statistics. As such, it would be interesting to conduct the same study using more rigorous statistical procedures. For instance, future studies could attempt to correlate the five employee dimensions that were under spotlight in this study. Regression analysis could also be applied to test causality between the same factors. In addition, the present study was also limited to five dimensions that shape employees perceptions about their organisation. However, there are other factors that were omitted and these could be considered for further extension of the study in the future. Similar studies could be conducted using the mixed method mode that integrates both qualitative and quantitative paradigms. This could lead to other interesting insights that could not be captured by the current study.

\section{Conclusions and Recommendations}

This study was conducted with the intent to investigate the perceptions of employees at selected tourism establishments as regards five elements of their jobs; namely, manager-employee relationship, working conditions, remuneration, teamwork and work allocation. It emerged that among these elements, employees were most satisfied with the level of teamwork and most dissatisfied with manager-employee relationship. With the exception of manager-employee relationships, all other elements were satisfactory. It can be concluded then that there are meaningful working conditions, equitable and market related remuneration, adequate levels of teamwork and an acceptable standard of work allocation at the selected tourism establishments. However, the relationships between employees and management are strained and need some attention.

A number of recommendations can be put forward, based on the findings of the study. To improve the relationship between management and employees, managers at the selected tourism establishments should receive training on how they can manage and motivate employees in a better way. Special attention should be placed on leadership styles, as these determine whether employees will be motivated or not. Employees should also be given an opportunity to highlight areas where they think managers can improve. A dispute resolution mechanism, such as an appropriate grievance procedure can be put in place which should be used to facilitate the proper handling of all disputes and conflicts between managers and employees. In addition, employees can also be given training on how to work positively with their managers.

Although it appears that the working conditions, remuneration, teamwork and work allocation at the selected tourism establishments are of an acceptable standard, continuous improvement is still merited. Physical aspects of the job such as office space, furniture, storage of materials can be improved regularly, e.g. new furniture for use by employees can be bought or the office layout and design can be improved (Chandrasaker, 2011). Work can be made more interesting and employees can be given equipment which makes their work easier, e.g. vacuum cleaners for cleaning staff and modern computers for office workers. Other ways of improving working conditions include ensuring that employees work in environments where there is a good temperature, low noise levels and high safety (Van Emmerik, 2004).

To maintain the satisfactory pay levels, an appropriate job evaluation system could be used as the basis for the salary structure. An effective system is the time rate system, which ensures that the salary is tied to the amount of time that the employee spent on the job (Estes \& Wang, 2008).

To continue enhancing teamwork, employees should receive training that encourages them to work in teams and gives them knowledge of the expected behavioural conduct in teams. Teams that perform well should be rewarded to stimulate more teamwork. Conflict within teams should be handled properly in order to avoid dysfunctional ties within the teams. Teams should be composed of manageable numbers of individuals, in order to make them more effective.

With reference to work allocation, further improvement may be attained by increasing the number of employees so that the working hours can be shared. Proper management of the available work shifts can be a useful tool in reducing work-overload among employees. Work rotation can also be implemented in which employees rotate in their work shifts, and can act as an instrument for the enhancement of the skills and expertise of employees. Employees should be granted the space to highlight their views about their allocated work so that management may become aware of the developments on the ground. 


\section{References}

Abd-El-Fattah, S.M. (2010). Longitudinal effects of pay increase on teachers' job satisfaction: a motivational perspective. The Journal of International Social Research, 3(10), 11-21.

Adebayo, S.O., \& Ogunsina, S. O. (2011). Influence of supervisory behaviour and job stress on job satisfaction and turnover intention of police personnel in Ekiti State. Journal of Management and Strategy, 2(3), 13-20.

Attwood, D., Khan, F., \&Veitch, B. (2006). Can we predict occupational accident frequency? Process Safety Environment, 84 (3), 208221.

Bandiera, O., Barankay, I., \& Rasul, I. (2007). Incentives for managers and inequality among workers: evidence from a firm level experiment. Quarterly Journal of Economics, 122, 729-773.

Barbie, J. (2010). South Africa, civil service strike. Global post. 4 September. Available at: http://www.globalpost.com/dispatch/southafrica/100903/south-africastrikegrinds-ountryhalt. Accessed: 16 June 2013.

Beardsley, R., Matzke, G.R., \& Rospond, R. (2008). Factors influencing the pharmacy faculty workforce. American Journal of Pharmaceutical Education, 72, 1-11.

Bebchuk, L.A., \& Fried, J. (2003). Executive compensation as an agency problem. Journal of Economic Perspectives, 17, 71-92.

Bhattacharya, C.B., \& Sankarsen, S. (2003). Consumer-company identification: a framework for understanding consumers' relationships with companies. Journal of Marketing, 67, 76-88.

Bockerman, P., \& IlmakunnaS, P. (2006). Do job disamenities raise wage or ruin job satisfaction? International Journal of Manpower, 27(3), 290-302.

Bolton, L. E. (2007). Believing in first mover advantage. Working Paper, Wharton School, University of Pennsylvania.

Booth, S., \& Hamer, K. (2000). Labour turnover in the retail industry: predicting the role of individual, organisational and environmental factors labour turnover in the retail industry. International Journal of Retail \& Distribution Management, 35(4), 289-307

Bono, J.E. \& Ilies, P. (2006). Charisma, positive emotions and mood contagion. Leadership Quarterly, 17, 317-334.

Boreham, N., Gray, P., \& Blake, A. (2006). Job satisfaction among newly qualified teachers in Scotland. Institute of Education. University of Stirling.

Cardoso, A.R., \& Portugal, P. (2006). Disentangling the minimum wage puzzle: an analysis of worker accessions and separations. Journal of the European Economic Association, 4(5), 988-1013.

Chandrasekar, K. (2011). Workplace environment and its impact on organisational performance in public sector organisations. International Journal of Enterprise Computing and Business Systems, 1(1), 1-16.

Chai, K., \& Xiao, X. (2012). Understanding design research: a bibliometric analysis of Design Studies (1996- 2010). Design Studies. 33(1), 24-43.

Collis, J., \& Hussey, R. (2009). Business research: a practical guide for undergraduate \& post-graduate students. $3^{\text {rd }}$ ed. London: Palgrave Macmillan.

Cropanzano, R., \& Mitchell, M.S. (2005). Social exchange theory: an interdisciplinary review. Journal of Management, 31(6), 874-900.

Croxon, B., Propper, C., \& Perkins, A. (2003). Do doctors respond to financial incentives? UK family doctors and the GP fund-holder scheme. Journal of Public Economics, 79, 375-398.

David, G. Rawley, E., \& Polsky, D. (2011). Integration and task allocation: evidence from patient care. National Bureau of Economic Research, Working Paper 17419. Available at: http://www.nber.org/papers/w17419. Accessed : 4/03/2013

Delarue, A., Van Hootegem, G., Procter, S., \& Burridhe, M. (2008). Team-working and organisational performance: a review of surveybased research. International Journal of Management Reviews, 10(2), 127-148.

Demps, J., Thornton, B., \& Baker, E. (2011). The role of age in employee perceptions of salary reductions. Journal of Behavioral Studies in Business, 21,1-8.

Drew, C.J., Hardman, M.L., \& Hosp, J. L. (2008). Designing and conducting research in education. Los Angeles, CA: Sage publications.

Duarte, A., I. Pen, L., Keller, L., \& Weissing. F. J. (2012). Evolution of self-organized division of labor in a response threshold model. Behavioral Ecology and Sociobiology, 66, 947-957.

Easley, R.F., \& Devaraj, S. (2003). Relating collaborative technology use to teamwork quality and performance: An empirical analysis. Journal of Management Information Systems, 19(4), 247-268

Ericksen, J., \& Dyer, L. (2005). Toward a strategic human resource management model of high reliability organisational performance. International Journal of Human resource Management, 16(1), 907-913.

Estes, S.B., \& Michael, J. (2005). Work-family policies and gender inequality at work: a Sloan Work and Family Encyclopedia entry. [online]. Available at: http://wfnetwork.bc.edu/encyclopedia_entry.php?id=1230\&area=All. Accessed: 12/03/2013.

Estes, S.B., \& Wang, J. (2008). Workplace incivility: impacts on individual and organizational Performance. Human Resource Development Review, 7, 218-240.

Fabiano, B., Curro, F., Reverberi, A.P., \& Pastorino, R.A. (2008). Statistical study on temporary work and occupational accidents: specific risk factors and risk management strategies. Safety Sciences, 46, 535-544.

Fay, C.H., \& Thompson, M.A. (2004). Minimum wage effects on labor market outcomes under search, matching, and endogenous contact rates. Econometrica, 74 (4), 1013-1062.

Ferreira, N. (2009). The relationship between psychological career resources and organisational commitment. Unpublished master's dissertation, Department of Human Resource Management, University of Pretoria, Pretoria. 
Forlan, P., \& Browne, J. (2005). A Review of performance measurement: towards performance management. Computers in Industry, 56, 663-680.

Frye, M. (2004). Equity-based compensation for employees: firm performance and determinations. Journal of Financial Research, 27 , 31-54.

Gilbreath, B., \& Benson, P.G. (2004). The contribution of supervisor behaviour to employee psychological well-being. Work \& Stress, 18, 255-266.

Guthrie, J., \& English, L. (1997). Performance information and program evaluation in the Australian public sector. International Journal of Public Sector Management, 10(3), 154-64.

Gavrel, F., \& Lebon, I. (2008). Minimum wage, unemployment benefits and labor market efficiency. Louvain Economic Review, 74, 5375.

Hall, C. (2003). Job satisfaction of sport management faculty in the U.S.A. Unpublished Doctoral thesis. Florida State University College of Education: Florida.

Harter, J. K., Schmidt, F.L., Asplund, J.W, Killham, E.A., \& Agrawal, S. (2010). Causal impact of employee work perceptions on the bottom line of organizations. Perspectives on Psychological Science, 5(4), 378-389.

Holcroft, C., \& Punnett, L. (2009).Work environment risk factors for injuries in wood processing. Journal of Safety Research, 40, 247255.

Hoegl, M., Weinkauf, K., \& Gemuenden, H.G. (2004). Interteam coordination, project commitment, and teamwork in multiteam R\&D projects: a longitudinal study. Organization Science, 15(1), 38-55.

Hughes, E.L., \& Parkes, K.R. (2013). Work hours and well-being: the roles of work-time control and work family interference. Social Indicators Research, 111(1), 235-253.

Ireland, R.D., Hoskisson, R.E., \& Hitt, M.A. (2009). The management of strategy: concepts and cases. Mason: Cengage Learning.

Kassahun, T. (2005). Level of organisational commitment: its correlates and predictors, Indian Journal of Industrial Relations, 41(1), 2936.

Katou, A.A., \& Budhwar, P.S. (2007). Human resource management systems and organisational performance: a test of a mediating model in the Greek manufacturing context. The International Journal of Human Resource Management, 17(7), 1223-1253.

Kim, J., McDuffie, J. P., \& Pil, F.K. (2010). Employee voice and organisational performance: Team versus representative influence. Human Relations, 63(3), 371, 394.

Kinzl, J.F., Knotzer, H., Traweger, C., Lederer, W., Heidegger, T., \& Benzer, A. (2004). Influence of working conditions on job satisfaction in anaesthetists. British Journal of Anaesthesia, 9(4), 102-133.

Krueger, B., Brazil, K., Lohfield, L., Edward, H.G., Lewis, D., \& Tjam, E. (2002). Organisation specific predictors of job satisfaction: Findings from a Canadian multi-site quality of work life cross-sectional survey. BMC Health Service Research, 2, 5-24.

Kuvaas, B., \& Dysvik, A. (2009). Perceived investment in employee development, intrinsic motivation and work performance. Human Resource Management Journal, 19(3), 217-236.

Lazear, E., \& Oyer, P. (2004). Internal and external labour markets: a personnel economics approach. Labour Economics, 11, $527-554$.

Lynch, A., \& Cole, E. (2006). Human factors in emergency care: the need for team resource management. Emergency Nursing, 14(2), $32-35$.

Lynch, W.D. (2004). Health affects work and work affects health. Business Health, 19, 31-37.

Lufkin, P. (2006). Technical communication managers face many challenges. Intercom, June, 3.

Malhotra, N.K. (2009). Marketing research: an applied orientation. 6rd ed. Eaglewood Cliffs, NJ: Prentice- Hall.

Martins, N. (2005). A model for managing trust. International Journal of Manpower, 23(8), 754-769

McClellan, C.M., Greenwood, R., \& Benger, J.R. (2006). Effect of an extended scope physiotherapy service on patient satisfaction and the outcome of soft tissue injuries in an adult emergency department. Emergency Medicine Journal, 23(5), 384-387.

Md-Sidin, S., Sambasivan, M., \& Ismail, I. (2010). Relationship between work-family conflict and quality of life. Journal of Managerial Psychology, 25(1), 58-81.

Mead, H., Witkowski, K., Gault, B., \& Hartmann, H. (2003). The influence of income, education, and work status on women's well-being. Womens' Health Issues, 11, 160-72.

Merriman, K. K., Schmidt, S. M., \& Dunlap-Hinkler, D. (2007). Profiling virtual employees: The impact of managing virtually. Journal of Leadership \& Organizational Studies, 14(6), 6-15.

Mubarak, A.R., Baba, I., Low,H.C., \& Quah, S.H. (2003).Quality of life of community-based schizophrenia patient in Penang, Malaysia. Australian \& New Zealand Journal of Psychiatry, 37(5), 577-586.

Nielsen, K., Yarker, J., Brenners, S.O., Randall, R., \& Borg, V. (2008). The importance of transformational leadership style for the wellbeing of employees working with older people. Journal of Advanced Nursing, 63(5), 465-475.

Nilsson, J. (2010). What's the problem? local officials' conceptions of weaknesses in their municipalities' crisis management capabilities. Journal of Contingencies and Crisis Management, 18(2), 83-95.

Noblet, A., Graffam, J., \& McWilliams, J. (2008). Sources of well-being and commitment of staff in the Australian Disability Employment Services. Applied Psychology, 55(2), 192-219.

Nurmala, D. (2010). Investigating the relationship between quality of work life and organizational commitment amongst employees in Malaysian firms. International Journal of Business and Management, 5(10), 324-342.

O'Donnell, S., \& Bulova, S.J. (2007). Worker connectivity: a review of the design of worker communication systems and their effects on task performance in insect societies. Insectes Sociaux, 54(3), 203-210. 
Origo, F., \& Pagani, L. (2009). Flexicurity and job satisfaction in Europe: the importance of perceived and actual job stability for wellbeing at work. Labour Economics, 16(5), 547- 555.

Rauhala, A., Kivimaki, M., Fagerstrom, L., Elovainio, M., Virtanen, M., \& Vahtera, J. (2007). What degree of work overload is likely to cause increased sickness absenteeism among nurses? evidence from the RAFAELA Patient Classification System. Journal of Advanced Nursing, 57(3), 286-95.

Rethinam, G.S., \& Ismail, M. (2008).Constructs of quality of work life: a perspective of information and technology professionals. European Journal of Social Science, 7(1), 58-71.

Roelen, C. A., Koopmans, P.C., \& Groothoff, J. W. (2008). Which work factors determine Job satisfaction? IOS Press, 30, $433-439$.

Salas, E., Sims, D.E., \& Burke, C.S. (2005). Is there a "big five" in teamwork? Small Group Research, 36(5), 555-599.

Schutte, K.J., \& Eaton, S.C. (2004). Perceived usability of work/family policies. Sloanwork and Family Excyclopedia. [online]. Available at: <http://wfnetwork.bc.edu/encyclopedia_entry.php?id=248\&area=All>. Accessed: 17/03/2013.

Shikdar, A.A., \& Sawaqed, N.M. (2003). Worker productivity and occupational health and safety issues in selected industries. Computers \& Industrial Engineering 45(4), 563-572.

Spitzer. D. (2007). Transforming performance measurement: rethinking the way we measure and drive organizational success. New York: Amacom.

Stedham, Y., Yamamura, J.H., \& Satoh, M. (2006).Gender and salary a study of accountants in Japan. Asia Pacific Journal of Human Resources, 44(1), 46-66.

Tangen, S. (2004). Performance measurement: from philosophy to practice. International Journal of Productivity and Performance Management, 53(8), 726-737.

Tohidi, H., \& Glard, P. (2008). The relationship between teamwork effectiveness and information technology. Journal of Applied Economic Sciences, 3(4), 13-21.

Turkyilmaz, A., Akman, G., Ozkan, C., \& Pastuszak, Z. (2011). Empirical study of public sector employee loyalty and satisfaction. Industrial Management \& Data Systems, 111(5), 675-696.

Van Den Berg, G. (2003). Multiple equilibria and minimum wages in labor markets with informational frictions and heterogeneous production technologies. International Economic Review, 44, 1337-1357.

Van Emmerik, H. (2004). For better and for worse: adverse working conditions and the beneficial effects of mentoring. Career Development International, 9 (4), 358-373.

Van Herpen, M.F.M., Van Praag, C.M., \& Cools, K. (2005). The effects of performance measurement and compensation on motivation: an empirical study. De Economist, 153(3), 303-29.

Varonen, M., \& Mattila, K. (2003). The safety climate and its relationship to safety practices, safety of the work environment and occupational accidents in eightwood-processing companies. Accident Anal. Prev. 3, 761-769.

Voss, Z.G., Cable, D.M. \& Voss, G. B. (2006). Organizational identity and firm performance: what happens when leaders disagree about "Who We Are?" Organization Science, 17(6), 741-55.

Watson, S., Maxwell, G.A., \& Farquharson, L. (2007). Line managers' views on adopting human resource roles: the case of Hilton (UK) hotels. Employee Relations, 29(1), 30-49.

Yang, H. (2008). Efficiency wages and subjective performance pay. Economic Inquiry, 46(2), 179-196.

Yavari, Y., Amirtash, A.M., \& Tondnevis, F. (2009). Comparison of quality of work life among faculty members in physical education faculties and departments. Journal of Movement Science, 7(13), 99-109.

Yeow, P.H.P., \& Sen, R.N. (2006). Productivity and quality improvements, revenue increment, and rejection cost reduction in the manual component insertion lines through the application of ergonomics. International Journal of Industrial Ergonomics, 36 (4), $367-377$.

Young, Y.A. (2009). Police in the eye of the storm. A quarterly publication of Police Community Relations Committee (P.C.R.C), 14-19.

Yoon, M.H., \& Suh, J. (2003).Organisational citizenship behaviors and service quality as external effectiveness of contact employees. Journal of Business Research, 56(8), 597-611.

Zairi, M., \& Jarrar, Y.F. (2006). Measuring organizational effectiveness in The NHS: management style and structure best practices. Total Quality Management, 12(78), 882-889. 